The contingent effect of social networking ties on Asian immigrant enterprises' innovation

Henry F. L. Chung

School of Communication, Journalism and Marketing

College of Business, Massey University, Auckland, New Zealand

Private Bag 102 904, North Shore, Auckland 0745, New Zealand

Email: h.chung@massey.ac.nz

\author{
Dorothy A. Yen \\ Brunel Business School \\ Brunel University London \\ Uxbridge, UB8 3PH, United Kingdom \\ Email: Dorothy.Yen@brunei.ac.uk
}

Cheng Lu Wang

Department of Marketing \& Quantitative Analysis

College of Business

University of New Haven

West Haven, CT 06516, USA

Email: cwang@newhaven.edu 


\title{
The contingent effect of social networking ties on Asian immigrant enterprises' innovation
}

\begin{abstract}
Immigrant enterprises' innovation has not received much research attention in the past. To address this gap, this study investigates how the contingent effect of immigrant enterprises' social network resources (business ties, political ties, and immigrant entrepreneurs' ethnic ties) affect the relationship between entrepreneurial orientation and innovation. Using data collected from 167 Asian immigrant enterprises operating in New Zealand, the findings show that immigrant entrepreneurs' business ties and ethnic ties positively enhance the effect of entrepreneurial orientation on innovation, whilst political ties have no effect on the overall relation between entrepreneurial orientation and innovation. Our study makes theoretical and managerial contributions to the studies of immigrant entrepreneurship in the business-to-business context, explaining the contingent effect of different social networking ties on immigrant enterprises' innovation.
\end{abstract}

Key words: Innovation, Entrepreneurial orientation, Business ties, Political ties, Immigrant entrepreneurs' ethnic ties, Immigrant enterprises, Business-to-Business marketing

\section{Introduction}

In today's demanding market, firms need to stay innovative in order to better fulfill customers' changing needs and to remain competitive. Innovation includes new product development (Atuahene-Gima \& Murray, 2007), first-to-market new services, and cutting-edge technological innovation (Wang \& Chung, 2013), as well as process and administrative innovation (JiménezJiménez \& Sanz-Valle, 2011). Innovation is closely associated with entrepreneurial orientation (EO), which refers to the extent of a firm's top management's strategic orientation in taking businessrelated risks and favoring changes, in order to actively compete with other firms (Miller, 2011; Arzubiaga et al., 2018). According to Pérez-Luño, Wiklund \& Cabrera (2011), innovation in firms requires proactiveness and risk, represented as a firm's entrepreneurial orientation. Therefore, firms with higher EO are more likely to engage in high risk-taking behavior, by capturing new opportunities and obtaining first mover advantages in the market place in order to stay innovative (Tan \& Vertinsky, 1996; Jiang, Liu, Fei \& Jiang, 2018). Nevertheless despite a growing interest in studying the relationship between EO and innovation (Engelen et al., 2012; Shan, Song \& Ju, 2016; Stam \& Elfring, 2008; Parkman, Holloway \& Sebastiao, 2012; Arzubiaga et al., 2018), existing 
research has not really discussed the influence of EO on immigrant enterprises' innovation activities (Omisakin et al., 2016; Parkman, Holloway \& Sebastiao, 2012; Vissak \& Zhang, 2014).

An immigrant enterprise is established and owned by an immigrant entrepreneur (Iyer \& Shapiro, 1999; Jiang, Kotabe, Hamilton \& Smith, 2016), who originated from a home country, but then migrated permanently to a new host country-of-residence (Chung, Rose \& Huang, 2012). Overall immigrant enterprises share several common features, such as a strong ethnic identity and mutual dependence, informal networks based on mutual trust and personal reputation, and a belief in the utility of knowledge from all possible sources (Gould, 1994; Iyer \& Shapiro, 1999). According to a survey of 69 countries in the 2012 Global Entrepreneurship Monitor, the majority of these countries reveal that immigrants are more entrepreneurial than native citizens, especially in growth-oriented ventures (Vandor \& Franke, 2016).

In the context of this study, Asian immigrant enterprises were selected in our sampling frame. Recent research indicates that Asian business-to-business (B2B) firms adopting a higher extent of EO are likely to display better innovation and performance (e.g., Chang, Wang \& Arnett, 2018). Therefore, when migrating to Western markets, it is likely that Asian immigrant entrepreneurs would commit to a business model similar to the ones adopted in their country-of-origin. Given that immigrant firms are mostly family owned (e.g., Iyer \& Sharpio, 1999; Pio \& Dana, 2014; Neville et al., 2014), they share many characteristics of family owned businesses, such as adopting a higher extent of EO, and are more likely to link with multi-faceted innovations (e.g., introduce new products, extend the product range, open up to new markets, enter new technology fields, improve existing product quality and production flexibility) (e.g., Arzubiaga et al., 2018).

Acknowledging the positive relationship between immigrants' EO and innovation, the focus of this paper, however, is to further explore the role of networking ties that moderate such a relationship from a social networking perspective. Compared to mainstream enterprises, immigrant enterprises tend to "have difficulties in accessing or acquiring human, social and financial capital because of 
disadvantaged founders' immigration status and various barriers" (Jiang et al., 2016, p.1286). Immigrant-owned enterprises may face compromised human capital because immigrant owners are, on average, less educated than non-immigrant owners and less familiar with the hiring legislation and practices in the host country (e.g., Hammarstedt, 2001; Neville et al., 2014). To compensate for their lack of access to the more tangible resources in the host country, immigrant enterprises often have to draw on their social networking ties as resources, to help them gain the desired competitive advantages (Sanders \& Nee, 1996; Iyer \& Shapiro, 1999; Chen, 2004). Social embeddedness theory posits that economic decisions interweave within social relationships (Granovetter, 1985). Whilst social networking ties are employed as resources to help improve firm performance, the contingent effect of social networking ties on innovation has received scant research attention. Wang \& Chung (2013) are one of the few exceptions that have examined the moderating effect of managerial ties on innovation; however, their work focused on firms in general, not immigrant enterprises. Also, their work did not really discuss the notion of innovation as a multi-dimensional concept that includes process and administrative innovation, in addition to product innovation.

Considering immigrant enterprises' lack of access to human, social, and financial capital, their reliance on social networking ties as contingent resources is likely to be much more prevalent than that of native firms. This is particularly the case in Asian immigrant enterprises, as social networking ties are always regarded as one's social capitals in the Asian cultural contexts and skillfully exercised by Asian firms to drive innovation and business performance (Yen \& Barnes, 2011; Saxenian, 2002; Geng, Mansouri, Atkins \& Yen, 2017; Wang \& Chung, 2013; Jiang et al., 2018). Recent research on EO and the social networking of Asian firms has revealed that the integration of ethnic social networks and EO can help these firms obtain valuable, rare, inimitable, and non-substitutable resources (Barney, 1991; Jiang et al., 2018). Nevertheless, acquisition of these resources is particularly difficult for Asian immigrant firms operating in Western host markets. Since Asian societies are particularly characterized as "connected culture" or collective culture (Wang \& Mowen, 
1997; Wang, Bristol, Mowen \& Chakraborty, 2000), in which people rely on their own ethnic ties, immigrant entrepreneurs' ethnic ties are important for them to maintain strong business and kinship links with their country-of-origin. Therefore, compared to immigrant enterprises from other cultural backgrounds (e.g., US), Asian immigrants are most likely to utilize different social networking ties as additional resources to promote their business success and drive innovation (Saxenian, 2002; Jiang et al., 2016; Li, Liu \& Liu, 2011; Jiang et al., 2018).

Acknowledging existing knowledge gaps, this paper proposes to investigate how the contingent effect of different social networking ties affects the relationship between Asian immigrant enterprises' entrepreneurial orientation and firm innovation. Specifically, this paper investigates the moderating effect of three social networking resources: a) business ties - an immigrant entrepreneur's managerial ties with other business stakeholders in the host country; b) political ties an immigrant entrepreneur's managerial ties with political parties and officials in the host country, and c) ethnic ties - an immigrant entrepreneur's managerial ties with others from the same countryof-origin or ethnicity. In doing so, it addresses the pressing matter that many Asian immigrant enterprises are struggling to stay innovative and maintain their competitiveness in the challenging host markets, failing to thrive and contribute back to the host market economy (Bates, Bradford \& Seamans, 2018).

Using data collected from 167 Asian immigrant enterprises operating in New Zealand, this research contributes to the immigrant entrepreneurship literature in several ways. Firstly, by theoretically arguing and empirically testing the contingent effects of different managerial ties on the EO-innovation relationship, this paper identifies social networking ties as firms' resources in explaining innovation. In particular, it sheds new light on innovation literature by showing how different types of managerial ties affect immigrant firms' innovation. Secondly, existing entrepreneurship literature lacks empirical evidence in studying Asian immigrant enterprises in the West. By investigating Asian immigrant enterprises' innovation and social networking ties, this 
paper also aids better understanding of the studies of Asian immigrant entrepreneurship. Finally, by revealing the various moderating effects of social ties on the EO-innovation relationship, our study provides practical implications for managers and policymakers who are keen to facilitate the business success of Asian immigrant enterprises in new host markets (Chung \& Tung, 2013; Jiang et al., 2016; Sheng, Zhou \& Li, 2011).

The remainder of this paper is structured as follows. It starts with a review of the relevant and current literature on immigrant enterprises, EO, and innovation as well as social networking resources, leading to the development of four research hypotheses, which together form the conceptual framework. The research approach and methodology are then explained ahead of the research findings and discussion. Finally, the implications of the study are discussed, followed by limitations and directions for future research.

\section{Literature review and hypotheses development}

\subsection{Current research on immigrant enterprises}

Existing research on immigrant enterprises can generally be divided into two key categories: immigrants and entrepreneurship, immigrant enterprises and international business strategies. Studies in the first group mainly focus on immigrants and entrepreneurship (e.g., Cain \& Spoonley, 2013; Pio \& Dana, 2014). They reveal that the key reasons for immigrants' entrepreneurship include underemployment and seeking financial security. Immigrant entrepreneurship is also closely related to the immigrant's social and economic networks and their deployment of human capital, engagement strategies, and transnational activities (Cain \& Spoonley, 2013). A key contribution of this stream of research is to provide a conceptualization for the linkage between immigrants and entrepreneurship. However, existing works have not discussed innovation and its relationship with immigrant entrepreneurship when conducting research on immigrant enterprises.

Studies in the second stream advance the immigrant entrepreneurship research by proposing that an immigrant entrepreneur firm's experience and knowledge can influence its selection of 
international business strategies such as the market entry modes in the country-of-origin (e.g., Tung \& Chung, 2010). For example, an immigrant enterprise is more likely to resort to higher resource commitment market entry modes (e.g., joint ventures and wholly owned operations) than lower resource commitment market entry modes (e.g., exporting) when entering into its country-of-origin market. In particular, research in this stream reveals a key linkage between an immigrant entrepreneur's social networks and foreign market entry strategies. Immigrants' social networks in the country-of-origin are shown to play a pivotal role in the selection of foreign market entry mode, specifically on the choice of country, location, and resource commitment (Chung \& Tung, 2013). However, extant literature has largely overlooked the effect of having social networking ties from the same country-of-origin on an immigrant enterprise's innovation. When addressing why immigrants are keen to embrace entrepreneurship and how immigrants' social networking ties influence international business strategies (e.g., Pio \& Dana, 2014; Tung \& Chung, 2010; Chung, Rose \& Huang, 2012), existing research has also failed to investigate the contingent effect of immigrant entrepreneurs' social networking ties on innovation. By addressing this knowledge gap and integrating the extant literature, our study will provide theoretical underpinnings and managerial guidance that can help immigrant enterprises stay innovative in their host markets (Bates, Bradford \& Seamans, 2018).

\subsection{Entrepreneurial orientation and innovation}

Entrepreneurship refers to a firm's ability to continually renew, innovate, and constructively take risks in its markets and bring innovations into business operation (Miller, 2011; Chang et al., 2018; Jiang et al., 2018). The traditional concept of entrepreneurship - entrepreneurial activity - refers to a one-time act that creates a new product or service or even an entirely new business - an act that challenges or creatively destructs existing products, services, and market relationships (Bygrave \& Hofer, 1991). Today, however, entrepreneurship is more likely to be viewed as a process, rooted in an organization's culture, rather than as a single event (Hult, Snow \& Kandemir, 2003; Arzubiaga et 
al., 2018), with the view of creating value by bringing together a unique package of resources to exploit an opportunity. This process itself includes the set of activities necessary to identify an opportunity, define a business concept, assess the needed resources, acquire those resources, and manage and harvest the venture (Morris, Schindehutte \& LaForge, 2001; Jiang et al., 2018). As such, entrepreneur orientation (EO) is regarded as a business philosophy, indicating the degree of strategic orientation to which top managers are inclined to engage in during the entrepreneurial process (Arzubiaga et al., 2018). EO refers to a firm-level strategic orientation that captures an organization's strategy-making, managerial philosophies, and firm behaviors (Anderson, Covin \& Slevin, 2009; Anderson et al., 2015; Eshima \& Anderson, 2017). The environmental dynamism, the risk-taking, and the proactive characteristics embedded within EO, affect both the generation and adoption of innovation (Pérez-Luño et al., 2011; Jiang et al., 2018). As such, EO is theoretically linked to innovation.

Innovation includes the adoption of any new product, process, or administrative innovation (Damanpour, 1991; Jiménez-Jiménez \& Sanz-Valle, 2011). In this study, we propose that an immigrant enterprise's innovation should be measured by the innovation activities of the entire firm, to better reflect an immigrant enterprise's overall innovative learning and its environmental adjustment capability. Following this conceptualization, we define the immigrant enterprise's innovation as the combination of product, process, and administrative innovation (Damanpour, 1991; Jiménez-Jiménez \& Sanz-Valle, 2011). Given that EO refers to a firm’s strategic orientation to support entrepreneurship that encourages the firm to engage in continuous innovation, opportunity seeking, and risk-taking, EO is identified as one of the key drivers that facilitates innovation (Harms et al., 2010; Arzubiaga et al., 2018). EO leads to the materialization of all sorts of innovative activities, for example, to support creativity and experimentation in product development and expansion, process restructuring and the development of new administrative systems and improvement of production flexibility, advanced technological leadership and research (Jiménez- 
Jiménez \& Sanz-Valle, 2011; Lumpkin \& Dess, 2001; Wang \& Chung, 2013; Arzubiaga et al., 2018).

Whilst earlier research has broadly discussed the relationship between EO and organizational learning capabilities and market effectiveness amongst all firms (e.g., Lisboa, Skarmeas \& Lages, 2011), more recent studies have paid attention to specific issues, such as the effect of EO on innovation from family owned firms, firms in the Asian emerging market, and immigrant firms (e.g., Fatoki \& Oni, 2014; Arzubiaga et al., 2018; Chang et al., 2018).

Empirical research shows that immigrant entrepreneurs with high innovative tendencies possess those characteristics of EO, such as being ahead of others in introducing new products (proactive), adopting a bold aggressive stance in exploring potential opportunities (aggressive and completive), and having a strong preference for high risk projects with chances of high return (risk-taking) (Fatoki \& Oni, 2014). Evidence also shows that immigrant enterprises, compared to native businesses, tend to be more entrepreneurial oriented and innovative. For example, in their study of immigrant entrepreneurs from West Africa (specifically Nigerians, Ghanaians, and Senegalese), Fatoki \& Oni (2014) found that immigrant entrepreneurs are adept at introducing new product lines and making changes to their product lines, suggesting that immigrant entrepreneurs are innovative.

The relatively high EO and innovative tendency of immigrant enterprises can be explained from various theoretical perspectives. As noted by Covin \& Slevin (1989), firms operating in hostile competitive environments, characterized by intense rivalry among firms, tend to adopt innovations with greater frequency than firms operating in more benign competitive settings. Metcalf, Modood \& Virdee (1996) contend that immigrants mainly opt for entrepreneurship for three basic reasons: (1) economic opportunity (immigrant enterprises have to rely on the market for success due to the lack of other opportunities); (2) cultural reason (immigrant entrepreneurs need to attain entrepreneurial goals in cultural affiliation, and (3) reactional reason (self-employment among immigrants is a reaction to their inability to secure a meaningful job). 
The disadvantage theory, or blocked mobility theory, suggests that since immigrants often have trouble in the labor market, they may develop entrepreneurship as an alternative means of employment and economic advancement (Hiebert, 2003; Min \& Bozorgmehr, 2003). Likewise, immigrant enterprises tend to be more entrepreneurial since an important prerequisite for the emergence of immigrant enclave economy is the entrepreneurial skills that help them achieve social mobility (Le, 2000; Portes \& Wilson, 1980). Vandor \& Franke (2016) explain the high entrepreneurial orientation of immigrants as a result of their extensive cross-cultural experience, which may 1) increase individuals' capabilities to identify promising business ideas, since they may transfer knowledge of product, service, and customer preferences from one country to another, and 2) stimulate creativity by combining diverse ideas, solutions, and customer problems in order to create something entirely new. Collectively extant research has provided a strong foundation on the base line relationship between EO and innovation among the immigrant enterprises. Hence, we propose:

Hypothesis 1: Entrepreneurial orientation positively influences the innovation of immigrant enterprises.

\subsection{Social Networking Resources}

Influenced by Confucianism, Asian immigrant enterprises in particular tend to employ managers' interpersonal ties (e.g., family, classmates, community, co-workers) as social networking resources to aid them in obtaining business information and advantages in operations (Sanders \& Nee, 1996; Iyer \& Shapiro, 1999; Chen, 2004). Asian culture is characterized as a relational or guanxi culture (Geng et al., 2017; Wang, 2007; Wang, Shi \& Barnes, 2015; Wang, Siu \& Barnes, 2008), wherein management ties are regarded as critical resources for Asian enterprises for gaining competitive competencies (Wang \& Chung, 2013). An immigrant entrepreneur's managerial ties reflect the immigrant firm's social capital that is captured from embedded resources in the social network (Lin, 1999). Social ties also reinforce one's social identity, social group membership, and entitlement to 
resources (He \& Wang, 2015). Therefore, from a resource-based view, it is generally agreed that social networking resources provide an explanation of competitive heterogeneity amongst immigrant firms (Helfat \& Peteraf, 2003), since those with more social networking ties are likely to have access to extra support, thus enjoying sustainable, competitive advantages.

\subsubsection{Business ties}

Business ties reflect the inter-organizational ties that a firm builds with key business players, with the aim of gaining access to a broad scope of knowledge, resources, and complementary capabilities of partners to perform innovation activities (Wu, 2011; Jiang et al., 2018). Business ties provide firms with access to a wider scope of knowledge and resources, to pool resources from other firms, and to understand and respond to changes occurring in the market environment, thus strengthening a firm's internal competence and leading to a better competitive advantage ( $\mathrm{Wu}, 2011)$. Taking on a relational governance perspective, existing research often regards business ties as beneficial and a means of enhancing the performance (Sheng, Zhou \& Li, 2011) and innovation (Wang \& Chung, 2013) of the firm. For example, research shows that when a firm adopts market orientation, business ties enhance the firm's innovation (Wang \& Chung, 2013).

Immigrant enterprises often face high risks due to high environmental uncertainty and limited resource availability (Iyer \& Shapiro, 1999; Jiang et al., 2016). Thus, business ties are of particular use because they can be utilized to provide immigrant entrepreneurs extensive access to critical information and intelligence, as well as additional resources (e.g., loans, customer trends, industrial permissions) that cannot be obtained easily in a new host market without these social connections (Wu \& Chen, 2012). In the B2B context, given that innovative ideas often result in information exchange among members in a supply chain, much of the firm's innovativeness hinges on the extent to which managers acquire and act on market intelligence through the firm's business ties (Wang \& Chung, 2013). Venturing from Asia to a Western host market (New Zealand), wherein both formal and informal institutions are different, business ties can help immigrant firms to acquire critical 
market information that provides insight for new product development (Cain \& Spoonley, 2013; Pio \& Dana, 2014).

In addition, when an immigrant enterprise adopts EO, strong business ties tend to increase the firm's learning capability and knowledge development while reducing the environmental uncertainty. Since EO encourages risk-taking and proactive behavior, business ties will help the immigrant firms to better appraise new opportunities and then engage in more innovative behaviors in terms of the development of new products, processes, and administrative systems. Therefore, we postulate that:

Hypothesis 2: Business ties positively moderate the relationship between entrepreneurial orientation and innovation of immigrant enterprises.

\subsubsection{Political ties}

As a newcomer to the host market, immigrant enterprises are often disadvantaged by their lack of strong legitimacy among the political network (Jiang et al., 2016). Operating in a new, uncertain, and often vulnerable host country environment, immigrant enterprises are often recommended to work on establishing social ties with government agencies and officials because political ties may enable firms to better understand the rules of the game and to achieve an advantageous position by having better regulatory resources (Sheng et al., 2011). However, extant research also shows that political ties may hinder a firm's innovation, particularly when political ties deviate firms' attention and resources away from entrepreneurial orientation and innovation to meet the demands of political networks (Wang \& Chung, 2013). Sometimes the favoritism received from governments due to strong political ties does not directly translate to firm innovation and may even be harmful to innovation (Chung, Wang, Huang \& Yang, 2016).

However, immigrant firms are different from domestic (non-immigrant) firms. Compared to domestic enterprises, immigrant enterprises suffer from the same issue of liability of foreignness that many multinational enterprises face when venturing into new markets (Zaheer, 1995). Sheng et al. 
(2011) point out that political ties lead to better firm performance when general government support is limited and technological turbulence is low. Unfortunately, immigrant enterprises are less likely to obtain support from the host market government due to their foreignness. In order to overcome the liability of foreignness and compete successfully against domestic competitors, from a resourcebased view, political ties are therefore considered as resources that provide immigrant enterprises firm-specific advantages (e.g., Jiang et al., 2018). For example, political ties can often help immigrant firms obtain scarce resources, and gain exclusive access to marketing intelligence and technology, thus being able to better forecast market demands, identify opportunities, and evaluate risks (Sun, Mellahi, Wright $\& \mathrm{Xu}, 2015)$. These political resources and intelligence help immigrant enterprises maintain their market positioning and stay ahead of the competition in the host market. As a firm-specific resource, political ties can help immigrant enterprises obtain more support from the host government and therefore further strengthen immigrant enterprises' capabilities in driving innovation in the host market. Following the argument above, we propose that:

Hypothesis 3: Political ties positively moderate the relationship between entrepreneurial orientation and innovation of immigrant enterprises.

\subsubsection{Immigrant entrepreneurs' ethnic ties}

Often immigrant entrepreneurs retain distinct systems of business operations, e.g., they maintain strong business and kinship links with their country-of-origin, and pursue different marketing strategies, e.g., importing and exporting products/services from and to their country-of-origin and focusing more on ethnic products (Chen \& Tan, 2009; Sequeira, Carr \& Rasheed, 2009). Immigrant entrepreneurs' networks are qualitatively different from other networks and are often overlooked by existing network theory (Light, Bhachu \& Karageorgis, 1989). Daniel, Radebaugh \& Sullivan (2002) show that immigration provides a good source of linkage among nations. The personal networks of immigrants have contributed greatly to the development of the economies in other countries and have 
made them attractive to foreign investment and promoted trade with these countries (Tung \& Chung, 2010).

The theory of social capital and the formation of migrant networks create the social foundation for immigrant entrepreneurs' ethnic or immigrant ties, which represent the social interaction with other immigrant affiliates from the same country-of-origin in the host country (Cleveland et al., 2009; Massey, 1990, 1999). Social human networks contribute significantly to immigrant entrepreneurship because new immigrants can have access to employment opportunities in businesses which are run by owners of the same ethnicity (Massey, 1999). Different to non-immigrant ties, immigrant ties provide valuable sources of mutual support and help maintain ethnic identity in a foreign environment (Cappellini \& Yen, 2013). The ethnic enclave theory suggests that as immigrants tend to cluster in close geographic areas, they develop migrant networks or interpersonal relations through which participants can exchange valuable resources and knowledge and establish entrepreneurship (Massey, 1999).

In addition, immigrant ties can increase an immigrant entrepreneur's knowledge development and/or confidence operating in the host country, as immigrant ties provide the emotional support network required by immigrants abroad (Cappellini \& Yen, 2015; Tung \& Chung, 2010). This may help the immigrants to adjust, adopt, debate, and resolve the possible business and cultural conflicts between home and host, leading to successfully living in two cultures (Berry, 2005). As the support network for immigrants, wherein information and resources could be exchanged informally for mutual benefits through various activities, immigrant entrepreneurs with more immigrant ties are regarded as more resourceful, which may help to better facilitate their EO, sharpen their vision, and help them better assess the market potential. In return, we argue that immigrant entrepreneurs with more immigrant ties are likely to gain more support with their understanding of the host market regulations and intelligence. Such knowledge thus enables them to engage in proactive product, process, and administrative system development, putting EO into practice (Damanpour, 1991; 
Jiménez-Jiménez \& Sanz-Valle, 2011). Light, Bhachu \& Karageorgis (1989) summarized three primary ways that the migration network might enhance immigrant entrepreneurship and innovation. First, the network feeds low cost co-ethnic labor to immigrant entrepreneurs just as it does to nonimmigrant entrepreneurs, thus, creating more immigrant entrepreneurs of small business owners. Second, immigrant networks provide important and credible economic information to immigrant entrepreneurs and would-be entrepreneurs because of the relationships of mutual trust that link members. Third, immigration networks also help enterprises access various kinds of mutual aid and assistance other than information. Many immigrant entrepreneurs acquire their initial training in business via an apprenticeship passed in the business of a co-ethnic. Based on the above discussion, we propose that EO's impact on innovation will be strengthened by immigrant ties.

Hypothesis 4: Immigrant entrepreneurs' ethnic ties positively moderate the relationship between entrepreneurial orientation and innovation of immigrant enterprises.

[Insert Figure 1 about here]

\section{Method}

\subsection{Sample and Data Collection}

This study collected data from Asian immigrant enterprises based in New Zealand. We have formed our sampling frame from a number of key data bases that are available in New Zealand. These include the Kompass (a global B2B directory), Yellow Pages and Government Companies Register data bases. Asian immigrant enterprises are listed in these vital data sources. We focused on these data bases as they can be commonly accessed by researchers who are based in other regions (e.g., UK, US, the EU). Our respondents were also affiliated business councils of China, Taiwan, Hong Kong, Korea, Japan, India, South East Asia, and the Chamber of Commerce and Statistics New Zealand. According to the latest government censuses in New Zealand, Asian immigrants (e.g., Chinese, Indian) are the third-largest ethnic group, with 471,708 Asian immigrants living there, and reaching 12 percent of the country's population (Statistics New Zealand, 2013, 2017). Based on the 
available information (e.g., members' profiles), an estimate of the immigrant enterprises listed in these sources is around 2,000. As our study aims to focus on the behavior of recent immigrants (Chung \& Tung, 2013), we mainly focus on the immigrant enterprises that were established in the last twenty years (Tung \& Chung, 2010), and whose main business areas are in the B2B context (e.g., suppliers to and distributors of other businesses in the host market). These criteria yielded around 1,000 immigrant enterprises. Due to the budget and time constraint, we randomly selected 575 immigrant enterprises across different sectors, which were contacted through a survey questionnaire. We contacted these immigrant enterprises, explained the importance of our study and sought their assistance. We explained to our respondents that the survey should be completed by senior executives (e.g., managing directors, chief executive officers, general managers, financial and marketing directors). Prior to the survey, a pilot study was conducted with eight immigrant entrepreneurs, during which we received very positive comments regarding the design of the questionnaire and their interest in this topic.

In total, 250 firms returned their completed survey, with 167 valid responses. Those that were invalid (83 questionnaires) were so because of incorrect addresses or being unable to participate (e.g., business closure). This yielded a response rate of 34 percent. Our respondents' countries-oforigin were from key immigrant source countries such as China (54\%), Hong Kong (7\%), India (16\%), Indonesia (1\%), Korea (5\%), Malaysia (4\%), Singapore (4\%), Taiwan (7\%), Thailand (1\%), and Vietnam (1\%). The respondents in our study had an average firm size at around 100 employees. The average year in New Zealand was around 8 years, suggesting these immigrant enterprises were also new to the country-of-residence market.

Furthermore, as our study has closely followed the research design of recent research into New Zealand immigrant enterprises (e.g., Chung \& Tung, 2013; Enderwick, Tung \& Chung, 2011; Chung et al., 2012; Tung \& Chung, 2010), we have not asked for profile information such as the age and 
gender of our respondents in our study. We have addressed this limitation in our suggestions for future research.

To assess non-response bias in the survey, early respondents were compared to late respondents, with the latter assumed to be similar to non-respondents. Early respondents denote those who replied to the survey within two months while late respondents represent those who responded to the study later than two months. The sample was split into two categories on the basis of the survey return dates (Armstrong \& Overton, 1977). We found no significant difference between these two groups on key variables such as managerial ties and innovation. Thus, non-response bias has not affected our findings.

\subsection{Measurement Scales}

A seven-point Likert scale was employed for all the measurements (1=strongly disagree; $7=$ strongly agree). The questionnaire was designed and conducted in English. All question items were related to the immigrant enterprise's business-to-business operation (i.e., marketing to other businesses such as suppliers, distributors, wholesalers, and retailers). In line with previous studies (e.g., Jiménez-Jiménez \& Sanz-Valle, 2011; Manu, 1992), we measured innovation from product, process, and administrative dimensions. Product innovation is operationalized by three items measuring to what extent the immigrant enterprises engage in developing new product/services. Process innovation and administrative innovation are also measured by three items each, addressing the degree of innovation in the process and the administrative system (see explanation of these items in Table 1). This combined construct offers a comprehensive picture of the entire firm's innovation activity. These three individual innovation components are highly correlated and thus can be combined as an aggregate measure (Jiménez-Jiménez \& Sanz-Valle, 2011).

\section{[Insert Table 1 about here]}

Business ties are estimated by the extent of top executives' connections, ties, and networks with top managers in the buyers, suppliers, and distributors of the country-of-residence market, wherein 
1=very little and 7=very extensive (Peng \& Luo, 2000; Sheng et al., 2011; Chung et al., 2016).

Political ties measure top managerial ties with political leaders, government officials in various industrial bureaus, and regulatory and supporting organizations of the country-of-residence market (Peng \& Luo, 2000; Sheng et al., 2011; Chung et al., 2016). Similar to business ties, the scale is from 1=very little to $7=$ very extensive. Immigrant entrepreneurs' ethnic ties represent the social ties with others of the same country-of-origin immigrant affiliates in the country-of-residence market (Cleveland et al., 2009). They are measured by the people they go to parties with (e.g., country-oforigin immigrant affiliates operating in other industries), people they get together with, people they have fun and relax with and country-of-origin friends ( $1=$ strongly disagree; $7=$ strongly agree).

Entrepreneurial orientation consists of three aspects - innovativeness, risk taking, and proactiveness, leading to seven items in total (Covin \& Slevin, 1989). Together they measure the immigrant firm's emphasis on R\&D, technological leadership, action initiation in terms of change, risk taking propensity, and opportunity exploitation. These items are also measured by a seven-point scale (see Table 1 for details). We have chosen these measurement items because they can equally apply to firms operating in different industrial areas (e.g., manufacturing, supplying, merchandising, and logistic). Recent research suggests that B2B firms (e.g., manufacturers, suppliers, and distributors) need to be entrepreneurially oriented (e.g., emphasis on R\&D, technological leadership, risk taking propensity, and opportunity exploitation), while developing their innovation capabilities and business-to-business strategies (e.g., Lisboa et al., 2011; Li, Liu \& Liu, 2011). Nevertheless, our study has not captured other entrepreneurial orientation items such as competitive aggressiveness and autonomy (Lumpkin \& Dess, 1996; Hughes \& Morgan, 2007) and future research may consider including these additional dimensions when measuring EO.

Control variables. Due to their potential effect on innovation performance, competitive rivalry and technological turbulence, measured on a 7 -point scale from $1=$ strongly disagree to $7=$ strongly agree, 
and industrial sector $(1=$ service vs $0=$ manufacturing) are also included as control variables (Peng \& Luo, 2000; Sheng et al., 2011; Zahra, 1993; Zahra, Neubaum \& Huse, 1997). An immigrant enterprise's export orientation is also included as a control variable, wherein $1=\mathrm{yes}, 0=$ no (Neville et al., 2014). Immigrant entrepreneurs' experience is measured by the number of years since the immigrant entrepreneur moved to the country-of-residence market (Su, Tsang \& Peng, 2009).

\subsection{Common method bias assessment}

To test the effect of common method bias, we adopted the marker variable (MV) technique that is recommended in the literature (Podsakoff et al., 2003; Sheng et al., 2011). We included a theoretical unrelated variable (MV) into our model and tested whether the inclusion of this variable would affect the correlation results of the original model. We chose a conflict variable (know each other better because of the way conflicts are handled; 1=strongly disagree; $7=$ strongly agree) (Sheng et al., 2011) and found that the inclusion of the MV did not alter the results (Table 2). Thus, we confirm that common method bias does not exist in this study.

\subsection{Reliability and validity}

As shown in Table 1, all the constructs' Cronbach's alpha values surpass the value of 0.5 (Nunnally, 1978), suggesting a high reliability of the constructs formulated. Our individual items' factor loadings are also greater than 0.7 (Anderson \& Gerbing, 1988). The composite reliability (CR) values of variables in the models are also larger than 0.7 (Fornell \& Larker, 1981). The constructs' square roots of the average variance extracted [(SQRT(AVE)] are also larger than the inter-construct correlations, or larger than the correlation coefficients under the diagonal. Hence, these statistics provide evidence of adequate validity and reliability (Chin, 2010).

\section{Results}

Hierarchical regression analysis was employed to test the proposed research hypotheses. In line with the existing literature, we adopted the mean-centered method for the constructs of the interaction terms (Aiken \& West, 1991). This method helps reduce the effect of multicollinearity 
when interpreting the interaction outcomes. The correlation coefficients among the main independent variables are generally low (Table 2), suggesting that multicollinearity is not a problem in this study. An additional regression using the variance-inflating factor (VIF) was also conducted to determine whether multicollinearity exists among the variables (Table 3). All VIF values are much smaller than the cut-off benchmark (10.0), confirming that multicollinearity is not a major concern.

\section{[Insert Table 2 and Table 3 about here]}

Table 3 presents three models to test our hypotheses (M1-M3). M1 shows the control variables, whilst M2 relates to the direct effect of the main variables, and M3 relates to the interaction results. We first explored the effect of control variables in M1, and then together with entrepreneurial orientation on innovation (M2). Finally, we investigated the interaction effects of entrepreneurial orientation, business ties, immigrant entrepreneurs' ethnic ties, and innovation in immigrant enterprises (M3). As shown in Table 4, the findings confirm our hypotheses, demonstrating that entrepreneurial orientation positively influences the innovation of immigrant enterprises (H1), business ties positively moderate the relationship between entrepreneurial orientation and innovation of immigrant enterprises (H2), and immigrant entrepreneurs' ethnic ties positively moderate the effect of entrepreneurial orientation on innovation of immigrant enterprises $(\mathrm{H} 4)^{1}$. However, our results cannot confirm that political ties positively moderate the overall relationship between entrepreneurial orientation and innovation of immigrant enterprises, and therefore $\mathrm{H} 3$ cannot be accepted. These results suggest that there are a variety of routes that lead to superior innovation,

\footnotetext{
${ }^{1}$ Considering that the three dimensions of innovation may involve different aspects of organizational learning and commitment, we ran separate regression models with each innovation dimension. The results demonstrate a fairly consistent pattern across three dimensions (Appendix 1-3), all supporting H1 (positive relationship between EO and innovation) and $\mathrm{H} 2$ (positive interaction between entrepreneurial orientation and business ties on all components of innovation) and H4 (positive interaction between entrepreneurial orientation and immigrant entrepreneurs' ethnic ties on all components of innovation), and with only minor variation in the H3 test result (where political ties have no significant effect on product and administrative innovation though having significant and negative impact on process innovation). The overall results, corroborated by high inter-component correlation coefficients, ranging from .577 (product-process innovation) to .663 (process-administrative innovation), indicate that it is appropriate to combine three components into an aggregate measure of innovation construct.
} 
relating to entrepreneurial orientation, business ties, political ties, and immigrant entrepreneurs' ethnic ties.

\section{Discussion and implications}

\subsection{Theoretical contributions}

By conceptually arguing and empirically demonstrating the moderating role of business ties and immigrant entrepreneurs' ethnic ties in the EO-Innovation relationship, this study yields three theoretical contributions to the literature of immigrant entrepreneurship in industrial marketing.

Firstly, the paper revisits the important question regarding the relationship between entrepreneurial orientation and firm innovation in the context of immigrant enterprises. By demonstrating that an Asian immigrant firm's entrepreneurial orientation has a significant impact on the firm's innovation in the Western host market, this paper confirms the importance of entrepreneurial orientation on firm innovation for immigrant enterprises. This new empirical evidence affirms the existing assumption that entrepreneurial orientation is a key driver of firm innovation (Covin \& Slevin, 1988; Harms et al., 2010). Firms with higher EO often engage in proactive behavior in terms of opportunity seeking, being forward-looking, and new product development ahead of the competition (Lumpkin \& Dess, 2001). Furthermore, our Asian immigrant firm's EO-innovation conceptualization can also significantly enhance recent B2B research that explores the effect of EO on firm performance and brand values. Our study suggests that EO not only affects performance and brand values but also influences innovation in the B2B context (Reijonen et al., 2015; Chang et al., 2018). Thus, further B2B research should consider including these outcome variables in their research design.

Secondly, by showing that immigrant firms' business ties and ethnic ties can positively moderate the effect of entrepreneurial orientation on firm innovation, this paper reveals the new contingent factors that are of importance to firm innovation. The finding sheds new light on the study of immigrant enterprises in industrial marketing by explaining the value of establishing social 
networking with members in their business networks and communities (Iyer \& Shapiro, 1999; Jiang et al., 2016; Neville et al., 2014). For example, the findings show that both business ties and immigrant entrepreneurs' ethnic ties can further strengthen the positive effect of entrepreneurial orientation on innovation. In particular, whilst business ties help immigrant firms gain access to exclusive market information and intelligence, immigrant entrepreneurs' ethnic ties can add to the understanding of the host market and provide better access to the required market knowledge, which facilitates effective decision-making. In sum, our findings demonstrate that it is important for future B2B research to identify and acknowledge the moderation factors (i.e., business ties and immigrant ethnic ties) that can enhance the impact of EO on innovation.

Lastly, our study shows that political ties do not have a positive impact on the overall relation between EO and innovation; however, they do have a negative effect on the relationship between EO and process innovation. Such an unexpected result suggests that political ties might have the doubleedge sword effect on immigrant entrepreneurs' process innovation, as noted in previous studies (Chung et al., 2016; Sheng et al., 2011). Acknowledging that political ties may provide immigrant firms with useful resources and government support, over-reliance on political ties may become a heavy burden for small-medium sized immigrant enterprises because excessive resources are required to establish and maintain these ties. Consequently, the development of these ties may take away some of the resources that are required for the advancement of innovative processes and negate the resource advantages associated with political ties. This finding extends recent B2B research that explores the dark side effect of political ties (Chung et al., 2016; Sheng et al., 2011).

\subsection{Managerial implications}

The research findings provide clear managerial implications for Asian immigrant firms based in New Zealand as well as in other Western developed economies (e.g., Australia, Canada, the USA, and the UK). In particular, the results clearly indicate that business and immigrant ties are positive enablers, yet political ties have little impact on the effect of entrepreneurial orientation on immigrant 
enterprises' innovation. Although political ties help offset the liability of foreignness, political ties are not necessarily beneficial to firm innovation. Therefore, to invest or not to invest in political ties should remain a strategic decision, depending on a firm's goals, mission, and market audit results. Instead, immigrant firms are advised to work on increasing and strengthening their managerial ties with their buyers, suppliers, distributors, and other network members, as well as managerial ties with fellow immigrants from the same country-of-origin or ethnic background. By doing so, immigrant firms will be able to better facilitate firm innovation regarding their products, services, processes, and administrative systems, thus increasing firm performance and presumably market competitiveness in the host market.

\subsection{Implications for policy makers}

Our findings offer some implications for policymakers who are keen to encourage Asian immigrant enterprises' innovation in the host market. Whilst business ties are positive enablers to immigrant enterprises' innovation, government policy makers should play an active role in encouraging and promoting business networking opportunities for immigrant enterprises, to help strengthen and broaden immigrant enterprises' business ties and to facilitate immigrant entrepreneurs' integration and interaction with other entrepreneurs. For example, hosting innovation conferences, workshops for small and medium sized enterprises, and sector-specific trade shows, and offering discounted fees to immigrant entrepreneurs. Also, government funding support could be dedicated to help promote ethnic cultural campaigns amongst ethnic communities, wherein immigrant entrepreneurs could interact with other immigrant affiliates and members from the same country-of-origin or of the same ethnicity. Such cultural events provide the needed social embeddedness for immigrant entrepreneurs (Cain \& Spoonley, 2013), which can further strengthen the relationship between EO and innovation.

\section{Limitations and future research directions}


This study has various limitations that may inspire future research. First, the sample examined is mainly related to Asian immigrants, though they are originally from diversified markets. Further enlarging the sample profile may offer a way to secure additional insight that would permit broader and more generalizations and provide a better base from which to make inferences and predictions. With a larger sample size, future research is encouraged to examine our conceptualization using subAsian immigrant enterprises and compare the results across varied Asian immigrant groups. By doing so, the results of our study can be better generalized. Second, since this study is based on immigrant enterprises operating in the Australasian region, future studies should test the validity of the findings in other geographic settings (e.g., North America, UK, and the EU). Third, there are other factors that may determine relationships with innovation in immigrant enterprises. For example, organizational learning and executive skill levels may bear a close relationship to innovation (Li \& Atuahene-Gima, 2001; Yalcinkaya, Calantone \& Griffith, 2007). As additional resources, they may also influence the EO-innovation relationship; hence future research is advised to consider them when studying innovation. Furthermore, as our study has closely followed the research design of recent research into New Zealand immigrant enterprises (e.g., Chung \& Tung, 2013; Enderwick et al., 2011; Chung et al., 2012; Tung \& Chung, 2010), we have not asked for the profile information such as the respondents' age and gender in our study. This limitation needs to be improved in future research due to their important role in immigrant entrepreneurship research. Lastly, due to the limits of the research scope and research objective of this study, we did not include some EO elements such as competitive aggressiveness and autonomy (Lumpkin \& Dess, 1996; Hughes \& Morgan, 2007). Future research may also consider these elements in the measurement of EO construct. Similarly, despite our best efforts, our sampling frame may not include all key immigrant enterprises because some immigrant enterprises are yet to be included in our data bases. Future research may benefit from using the snowball sampling technique where 
existing study subjects recruit future subjects from among their acquaintances as a supplementary sampling frame (Goodman, 1961).

\section{REFERENCES}

Aiken, L. S. and West, S. G. (1991). Multiple Regression: Testing and Interpreting Interaction. Newbury Park, CA: Sage Publications.

Anderson, B. S., Kreiser, P. M., Kuratko, D. F., Hornsby, J. S. \& Eshima, Y. (2015). Reconceptualizing entrepreneurial orientation. Strategic Management Journal, 36, 579-1596.

Anderson, B., Covin, J. \& Slevin, D. (2009). Understanding the relationship between entrepreneurial orientation and strategic learning capability: An empirical investigation. Strategic Entrepreneurship Journal, 3(3), 218-240.

Anderson, J. C. \& Gerbing, D. W. (1988). Structural equation modeling in practice: A review and recommended two-step approach. Psychological Bulletin, 103(3), 411-423.

Armstrong, J. S. \& Overton, T. S. (1977). Estimating nonresponse bias in mail surveys. Journal of Marketing Research, 16, 396-402.

Arzubiaga, U., Kotlar, J., Massis, A. D., Maseda, A. \& Iturralde, T. (2018). Entrepreneurial orientation and innovation in family SMEs: Unveiling the (actual) impact of the Board of Directors. Journal of Business Venturing, 33, 455-469.

Atuahene-Gima, K. \& Murray, J. Y. (2007). Exploratory and Exploitative Learning in New Product Development: A Social Capital Perspective on New Technology Ventures in China. Journal of International Marketing, 15(2), 1-29.

Barney, J. (1991). Firm resources and sustained competitive advantage, Journal of Management, 17(1), 99-120.

Bates, T., Bradford, W.D. \& Seamans, R. (2018). Minority entrepreneurship in twenty-first century America. Small Business Economics, 50(3), 415-427.

Berry, J.W. (2005). Acculturation: Living successfully in two cultures. International Journal of Intercultural Relations, 29(6), 697-712.

Boso, N., Story, V. M., \& Cadogan, J. W. (2013). Entrepreneurial orientation, market orientation, network ties, and performance: Study of entrepreneurial firms in a developing economy. Journal of Business Venturing, 28, 708-727.

Bygrave, W. D. \& Hofer, C. W. (1991). Theorizing about entrepreneurship. Entrepreneurship Theory and Practice, 16(2), 13-22.

Cain, T. \& Spoonley, P. (2013). Making it work: The mixed embeddedness of immigrant entrepreneurs in New Zealand, Discussion Paper Series, Forschungsinstitut zur Zukunft der Arbeit, No. 7332, Institute for the Study of Labor (IZA), Bonn.

Cappellini, B. \& Yen, D. A. (2013). Little Emperors in the UK: acculturation and food over time. Journal of Business Research, 66(8), 968-974.

Cappellini, B. \& Yen, D. A. (2015). A space of one's own: spatial and identity liminality in an online community of mothers. Journal of Marketing Management, 29(6), 545-561.

Chang, Y., Wang, X. \& Arnett, D. B. (2018). Enhancing firm performance: The role of brand orientation in business-to-business marketing. Industrial Marketing Management, 72, 17-25.

Chen, M. (2004). Asian management systems: Chinese, Japanese and Korean styles of business. Cengage Learning EMEA.

Chen, W. \& Tan, J. (2009). Understanding transnational entrepreneurship through a network lens: Theoretical and methological considerations. Entrepreneurship Theory and Practice, 33(5), 10791091. 
Chin, W. W. (2010). How to write up and report PLS analyses. In V. Esposito Vinzi, W. W. Chin, J. Henseler \& H. Wang, eds., Handbook of partial least squares, Springer Handbooks of Commputational Statistics. Heidelberg, Berlin, Germany: Springer-Verlad.

Chung, H. F. L., Rose, E. \& Huang, P-H. (2012). Linking international adaptation strategy, immigrant effect and performance: The case of home-host and cross-market scenario. International Business Review, 21(1), 40-58.

Chung, H. F. L. \& Tung, R. L. (2013). Immigrant social networks and foreign entry: Australia and New Zealand firms in the European Union and Greater China. International Business Review, 22, 18-31.

Chung, H., Wang, C. L., Huang, P. \& Yang, Z. (2016). Organizational capabilities and business performance: When and how the dark side of managerial ties matter? Industrial Marketing Management, 55(May), 70-82.

Cleveland, M., Laroche, M., Pons, F. \& Kastoun, R. (2009). Acculturation and consumption: Textures of cultural adaptation. International Journal of Intercultural Relations, 33, 196-212.

Covin, J. G. \& Slevin, D. P. (1988). The influence of organization structure on the utility of an entrepreneurial top management style. Journal of Management Studies, 25(3), 217-234.

Covin, J. G. \& Slevin, D. P. (1989). Strategic management of small firms in hostile and benign environments. Strategic Management Journal, 10, 75-87.

Damanpour, F. (1991). Organizational innovation: a meta-analysis of effects of determinants and moderators. Academy of Management Journal, 34(3), 550-90.

Daniel, J. D., Radebaugh, L. H. \& Sullivan, D. P. (2002). Globalization and business. New Jersey: Prentice Hall.

Enderwick, P., Tung, R. \& Chung, H. F. L. (2011). Immigrant effects and international business activity: an overview. Journal of Asia Business Studies, 5(1), 6-22.

Engelen, A., Gupta, V., Stenger, L. \& Brettel, M. (2012). Entrepreneurial orientation, firm performance, and the moderating role of transformational leadership behaviors. Journal of Management, 41(4), 1069-1097.

Eshima, Y. \& Anderson, B. S. (2017). Firm growth, adaptative capability and entrepreneurial orientation. Strategic Management Journal, 38, 770-779.

Fatoki, O. and Oni, O. (2014). The entrepreneurial orientation of immigrant entrepreneurs in South Africa, Mediterranean. Journal of Social Sciences, 5(20), 497-502.

Fornell, C. \& Larker, D. F. (1981). Evaluating structural equation models with unobservable variables and measurement error. Journal of Marketing Research, 18(1), 39-50.

Geng, R., Mansouri, A., Atkins, E. \& Yen, D. (2017). The role of Guanxi in green supply chain management in Asia's emerging economies: A conceptual framework. Industrial Marketing Management, 63(May), 1-17.

Goodman, L.A. (1961). Snowball sampling. Annals of Mathematical Statistics, 32(1), 148-170.

Gould, D. M. (1994). Immigrant links to the home country: Empirical implications for US bilateral trade flows. The Review of Economics and Statistics, 76(2), 302-316.

Granovetter, M. (1985). Economic action and social structure: the problem of embeddedness. American Journal of Sociology, 91, 481-510.

Hammarstedt, M. (2001). Immigrant self-employment in Sweden: its variation and some possible determinants. Entrepreneurship and Regional Development, 13, 147-161.

Harms, R., Reschke, C. H., Kraus, S. \& Fink, M. (2010). Antecedents to innovation and growth: Analyzing the impact of entrepreneurial orientation and management by objectives. International Journal of Technology Management, 52(1-2), 135-152.

He, J. \& Wang, C. L. (2015). The impact of cultural identity and consumer ethnocentrism on buying domestic vs. import brands: An empirical study in China. Journal of Business Research, 68 (6), 1225-1233. 
Helfat, C. E. \& Peteraf, M.A. (2003). The dynamic resource - based view: Capability lifecycles. Strategic Management Journal, 24(10), 997-1010.

Hiebert, D. (2003). Canada: a false consensus. In R. Kloosterman \& J. Rath, eds., Immigrant entrepreneurs: venturing abroad in the age of globalization. New York, NY: Berg, 39-60.

Hughes, M. \& Morgan, R.E. (2007). Deconstructing the relationship between entrepreneurial orientation and business performance at the embryonic stage of firm growth. Industrial Marketing Management, 36, 651-661.

Hult, G. T., Snow, C. C. \& Kandemir, D. (2003). The roll of entrepreneurship in building cultural competitiveness in different organizational types, Journal of Management, 29(3), 401-426.

Iyer, G. R. \& Shapiro, J. M. (1999). Ethnic entrepreneurial and marketing systems: Implications for the global economy. Journal of International Marketing, 7(4), 83-110.

Jiang, G., Kotabe, M., Hamilton, R. D. \& Smith, S. W. (2016). Early internationalization and the role of immigration in new venture survival. International Business Review, 25(6), 1285-1296.

Jiang, X., Liu, H., Fey, C. \& Jiang, F. (2018). Entrepreneurial orientation, network resource acquisition, and firm performance: A network approach. Journal of Business Research, 87, 46-57.

Jiménez-Jiménez, D. \& Sanz-Valle, R. (2011). Innovation, organizational learning, and performance. Journal of Business Research, 64, 408-417.

Le, A. T. (2000). The determinants of immigrant self-employment in Australia. The International Migration Review, 34(1), 183-214.

Li, H. \& Atuahene-Gima, K. (2001). Product innovation strategy and the performance of new technology ventures in China. Academy of Management Journal, 44(6), 1123-1134.

Li, Y., Liu, Y. \& Liu, H. (2011). Co-opetition, distributor's entrepreneurial orientation and manufacturer's knowledge acquisition: Evidence from China. Journal of Operations Management, 29, 128-142.

Light, I., Bhachu, P. \& Karageorgis, S. (1989). Migration Networks and Immigrant Entrepreneurship. UCLA: Institute for Social Science Research, (online). Retrieved from https://escholarship.org/uc/item/50g990sk.

Lin, N. (1999). Building a network theory of social capital. Connections, 22(1), 28-51.

Lindell, M. K. \& Whitney, D. J. (2001). Accounting for common method variance in cross-sectional research designs. Journal of Applied Psychology, 86(1), 114-21.

Lisboa, A., Skarmeas, D. \& Lages, C. (2011). Entrepreneurial orientation, exploitative and explorative capabilities, and performance outcomes in export markets: A resource-based approach. Industrial Marketing Management, 40, 1274-1284.

Lumpkin, G. T. \& Dess, G. G. (1996). Clarifying the entrepreneurial orientation construct and linking it to performance, Academy of Management Review, 21(1), 135-172.

Lumpkin, G. T. \& Dess, G. G. (2001). Linking two dimensions of entrepreneurial orientation to firm performance: The moderating role of environment and industry life cycle. Journal of Business Venturing, 16(5), 429-451.

Manu, F. (1992). Innovation orientation, environment and performance: a comparison of U.S. and European markets. Journal of International Business Studies, 23(2), 333-59.

Massey, D. S. (1990). Annals of the American Academy of Political and Social Science. Annals of the American Academy of Political and Social Science, 510. World Population: Approaching the Year 2000.

Massey, D. S. (1999). Why Does Immigration Occur? A Theoretical Synthesis. In: C. Hirschman, P. Kasinitz and J. DeWind, eds., The Handbook of International Migration: The American Experience, New York: Russell Sage Foundation.

Metcalf, H., Modood, T. \& Virdee, S. (1996). Asian self-employment: The interaction of culture and economics in England. London: Policy Studies Institute. 
Miller, D. (2011). Miller (1983) Revisited: A reflection on EO research and some suggestions for the future. Entrepreneurship Theory and Practice, 35(5), 873-894.

Min, P. G. \& Bozorgmehr, M. (2003). United States: The entrepreneurial cutting edge. In: R. Kloosterman \& J. Rath, eds., Immigrant entrepreneurs: venturing abroad in the age of globalization, Oxford: Berg, 17-37.

Morris, M.H., Schindehutte, M. \& LaForge, R.W. (2001). The emergence of entrepreneurial marketing: nature and meaning. In: Working paper, Department of Marketing College of Business Administration. University of Hawaii, Honolulu, Hawaii.

Neville, F., Orser, B., Riding, A. \& Jung, O. (2014). Do young firms owned by recent immigrants outperform other young firms? Journal of Business Venturing, 29, 55-71.

Nunnally, J. C. (1978). Psychometric theory. 2nd ed. New York: McGraw-Hill.

Omisakin, O. M., Nakhid, C., Littrell, R. \& Verbitsky, J. (2016). Entrepreneurial orientation among migrants and small and medium enterprises. Journal of Business Administration Research, 5(1), $8-22$.

Parkman, I. D., Holloway, S. S. \& Sebastiao, H. (2012). Creative industries: aligning entrepreneurial orientation and innovation capacity. Journal of Research in Marketing and Entrepreneurship, 14(1), 95-114.

Peng, M. W. \& Luo, Y. (2000). Managerial ties and firm performance in a transition economy: The nature of a micro-macro link. Academy of Management Journal, 43(3), 486-501.

Pérez-Luño, A., Wiklund, J. \& Cabrera, R. V. (2011). The dual nature of innovative activity: How entrepreneurial orientation influences innovation generation and adoption. Journal of Business Venturing, 26(5), 555-571.

Pio, E. \& Dana, L. P. (2014). An empirical study of Indian entrepreneurs in Christchurch, New Zealand. International Journal of Entrepreneurship and Small Business, 22(1), 17-35.

Podsakoff, P. M., MacKenzie, S. B., Lee, J. Y. \& Podsakoff, N. P. (2003). Common method biases in behavioral research: A critical review of the literature and recommended remedies. Journal of Applied Psychology, 88(5), 879-903.

Portes, A. \& Wilson, K. (1980). Immigrant enclaves: An analysis of the labor market experiences of Cubans in Miami. American Journal of Sociology, 86(2), 295-319.

Reijonen, H., Hirvonen, S., Nagy, G., Laukkanen, T. \& Gabrielsson, M. (2015). The impact of entrepreneurial orientation on B2B branding and business growth in emerging markets. Industrial Marketing Management, 51, 35-46.

Sanders, J.M. \& Nee, V. (1996). Immigrant self-employment: The family as social capital and the value of human capital. American sociological review, 61(2), 231-249.

Saxenian, A. (2002). Silicon valley's new immigrant high-growth entrepreneurs. Economic Development Quarterly, 16, 20-31.

Sequeira, J. M., Carr, J. C. \& Rasheed, A. A. (2009). Transnational entrepreneurship: Determinants of firm type and owner attributions of success. Entrepreneurship Theory \& Practice, 33(5), 10231044.

Shan, P., Song, M. \& Ju, X. (2016). Entrepreneurial orientation and performance: Is innovation speed a missing link? Journal of Business Research, 69(2), 683-690.

Sheng, S., Zhou, K. Z. \& Li, J. J. (2011). The effects of business and political ties on firm performance: Evidence from China. Journal of Marketing, 75(January), 1-15.

Stam, W. \& Elfring, T. (2008). Entrepreneurial orientation and new venture performance: The moderating role of intra- and extra-industry social capital. Academy of Management Journal, 51(1), 97-111.

Statistics New Zealand. (2013). Census. http://www.stats.govt.nz/Census/2013-census/profile-andsummary-reports/quickstats-culture-identity/asian.aspx. Wellington, New Zealand. 
Statistics New Zealand. (2017). Migration. http://www.stats.govt.nz/browse_for_stats/population/ Migration.aspx. Wellington, New Zealand.

Su, Y. S., Tsang, E. W. K. \& Peng, M. W. (2009). How do internal capabilities and external partnerships affect innovativeness? Asia Pacific Journal of Management, 26, 309-331.

Sun, P., Mellahi, K., Wright, M. \& Xu, H. (2015). Political tie heterogeneity and the impact of adverse shocks on firm value. Journal of Management Studies, 52(8), 1036-1063.

Tan, B. \& Vertinsky, I. (1996). Foreign direct investment by Japanese electronics firms in the United States and Canada: Modeling the timing of entry. Journal of International Business Studies, 27, 655-681.

Tung, R. \& Chung, H. (2010). Diaspora and trade facilitation: The case of ethnic Chinese in Australia. Asia Pacific Journal of Management, 27, 371-392.

Vandor, P. \& Franke, N. (2016). Why are immigrants more entrepreneurial? Harvard Business Review, (online). Available at: https://hbr.org/2016/10/why-are-immigrants-more-entrepreneurial.

Vissak, T. \& Zhang, X. (2014). Chinese immigrant entrepreneurs' involvement in internationalization and innovation: Three Canadian cases. Journal of International Entrepreneurship, 12(2), 183-201.

Wang, C. L. (2007). Guanxi vs. relationship marketing: Exploring underlying differences. Industrial Marketing Management, 36, 81-86.

Wang, C. L. \& Chung, H. (2013). The moderating role of managerial ties in market orientation and innovation: An Asian perspective. Journal of Business Research, 66(12), 2431-2437.

Wang, C. L., Bristol, T., Mowen, J. C. \& Chakraborty, G. (2000). Alternative modes of selfconstrual: Dimensions of connectedness-separateness and advertising appeals to the cultural and gender-specific self. Journal of Consumer Psychology, 9(2), 107-115.

Wang, C. L. \& Mowen, J. C. (1997). Separateness-connectedness self-schema: Scale development and application to message construction. Psychology \& Marketing, 14(2), 185-207.

Wang, C. L., Shi, Y. \& Barnes, B. R. (2015). The role of satisfaction, trust and contractual obligation on long-term orientation among Chinese and Western managers. Journal of Business Research, 68(3), 473-479.

Wang, C. L, Siu, N. \& Barnes, B. R. (2008). The significance of trust and renqing in the long-term orientation of Chinese business-to-business relationships. Industrial Marketing Management, 37(7), 819-824.

$\mathrm{Wu}, \mathrm{J}$. (2011). Asymmetric roles of business ties and political ties in product innovation. Journal of Business Research, 64(11), 1151-1156.

Wu, J. \& Chen, X. (2012). Leaders' social ties, knowledge acquisition capability and firm competitive advantage. Asia Pacific Journal of Management, 29(2), 331-350.

Yalcinkaya, G., Calantone, R. J. \& Griffith, D. A. (2007). An examination of exploration and exploitation capabilities: Implications for product innovation and market performance. Journal of International Marketing, 15(4), 63-93.

Yen, D. A. \& Barnes, B. R. (2011). Analyzing stage and duration of Anglo-Chinese business-tobusiness relationships. Industrial Marketing Management, 40(3), 346-357.

Zaheer, S. (1995). Overcoming the liability of foreignness. Academy of Management journal, 38(2), 341-363.

Zahra, S. (1993). Environment, corporate entrepreneurship and financial performance: A taxonomic approach. Journal of Business Venturing, 8(4), 319-340.

Zahra, S. A., Neubaum, D. O. \& Huse. M. (1997). The effect of the environment on export performance among telecommunications. Entrepreneurship: Theory and Practice, 22(Fall), 2546. 
Figure 1: Conceptual Framework

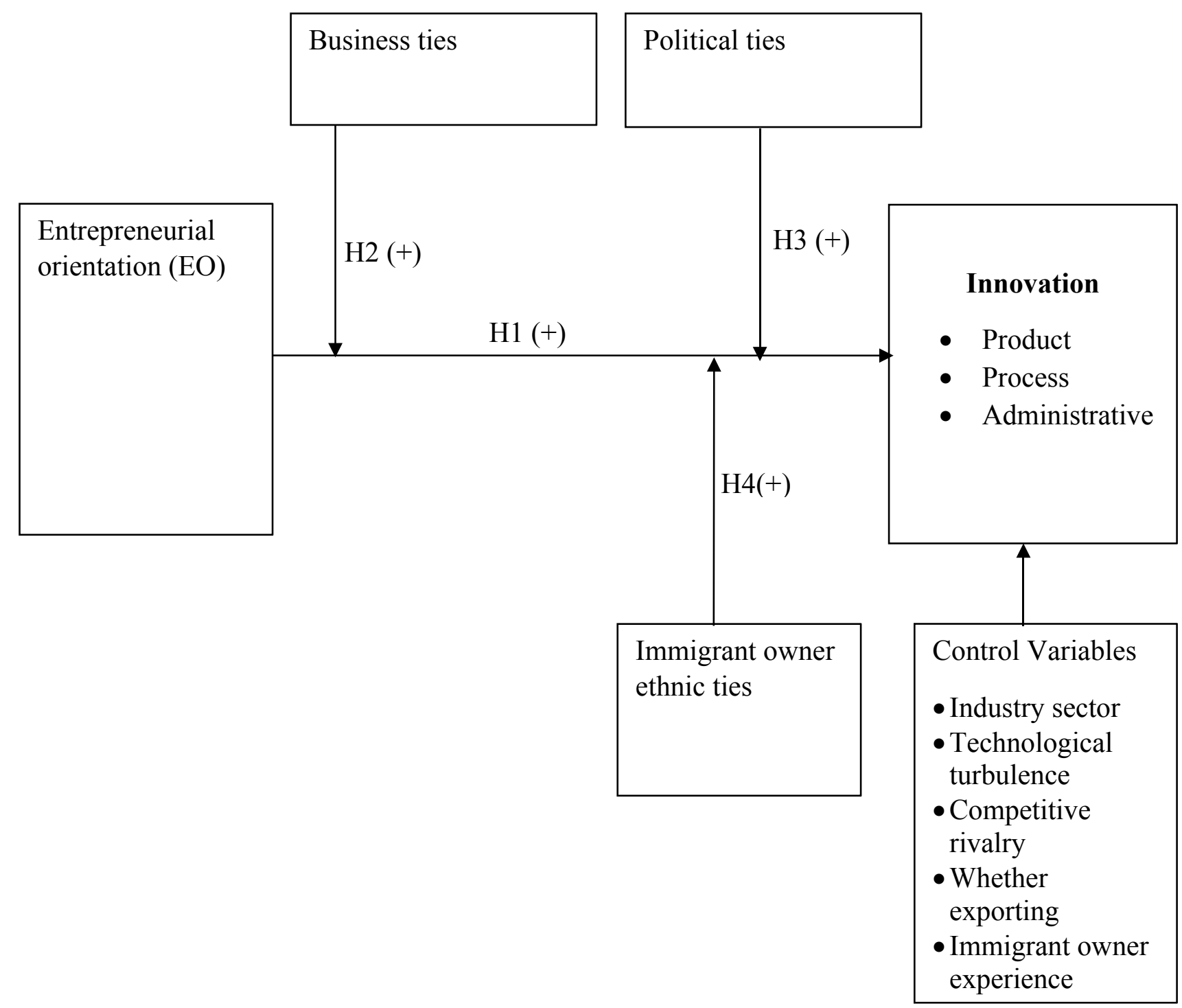


Table 1: Constructs' information

\begin{tabular}{|c|c|c|}
\hline & \multicolumn{2}{|c|}{$\begin{array}{c}\text { Immigrant enterprise } \\
(\mathbf{N}=167)\end{array}$} \\
\hline Constructs & Mean values & $\begin{array}{c}\text { Alpha, CR, Factor } \\
\text { loadings }\end{array}$ \\
\hline $\begin{array}{l}\text { Innovation - } 2^{\text {nd }} \text { order (Damanpour, 1991; Jiménez-Jiménez } \\
\quad \& \text { Sanz-Valle, 2011) }\end{array}$ & & $\alpha=0.90, \mathrm{CR}=0.96$ \\
\hline Product innovation $(1=$ strongly disagree; $7=$ strongly agree $)$ & & $\alpha=0.93, \mathrm{CR}=0.96$ \\
\hline $\begin{array}{l}\text { We have introduced a large number of new } \\
\text { product/services }\end{array}$ & 4.35 & 0.93 \\
\hline We are a pioneer in introducing new product/services & 4.32 & 0.95 \\
\hline $\begin{array}{l}\text { We effectively develop new product/services in terms of } \\
\text { hours/persons, teams, and training involved }\end{array}$ & 4.34 & 0.94 \\
\hline Process innovation ( $1=$ strongly disagree; $7=$ strongly agree) & & $\alpha=0.95, \mathrm{CR}=0.97$ \\
\hline We have introduced a large number of changes in process & 4.26 & 0.95 \\
\hline We are a pioneer in introducing new processes & 4.19 & 0.96 \\
\hline $\begin{array}{l}\text { We cleverly respond to new processes introduced by other } \\
\text { firms in the same sector }\end{array}$ & 4.20 & 0.95 \\
\hline $\begin{array}{l}\text { Administrative innovation }(1=\text { strongly disagree; } 7=\text { strongly } \\
\text { agree) }\end{array}$ & & $\alpha=0.95, \mathrm{CR}=0.97$ \\
\hline Our novelty of administrative systems is high & 4.22 & 0.95 \\
\hline We always search for new administrative systems & 4.30 & 0.96 \\
\hline $\begin{array}{l}\text { We are a pioneer in introducing new administrative } \\
\text { systems }\end{array}$ & 4.17 & 0.96 \\
\hline $\begin{array}{l}\text { Business ties (Ties with business organizations of country- } \\
\text { of-residence) (Boso, Story \& Cadogan,2013; Chung et al., } \\
\text { 2016) ( } 1=\text { very little; 7=very extensive) }\end{array}$ & & $\alpha=0.77, \mathrm{CR}=0.99$ \\
\hline Top managers at buyer firms & 5.16 & 0.69 \\
\hline Top managers at supplier firms & 4.73 & 0.82 \\
\hline Top managers at distributor firms & 4.92 & 0.87 \\
\hline $\begin{array}{l}\text { Political ties (Ties with political entities of country-of- } \\
\text { residence) (Boso et al., 2013; Chung et al., 2016) (1=very } \\
\text { little; } 7=\text { very extensive) }\end{array}$ & & $\alpha=0.85, \mathrm{CR}=0.91$ \\
\hline Political leaders in various levels of governments & 4.68 & 0.93 \\
\hline Officials in various industrial bureaus & 4.71 & 0.90 \\
\hline Officials in regulatory and supporting organizations & 4.42 & 0.81 \\
\hline $\begin{array}{l}\text { Immigrant entrepreneurs' ethnic ties (Ties with country-of- } \\
\text { origin immigrant affiliates) (Cleveland et al., 2009) } \\
(1=\text { strongly disagree; } 7=\text { strongly agree })\end{array}$ & & $\alpha=0.75, \mathrm{CR}=0.91$ \\
\hline $\begin{array}{l}\text { Most people I go to parties with are from the same country- } \\
\text { of-origin (COO) }\end{array}$ & 5.07 & 0.81 \\
\hline I get together with the same COO people very often & 5.01 & 0.78 \\
\hline $\begin{array}{l}\text { Most of the people at the places I go to have fun and relax } \\
\text { with are the same COO people }\end{array}$ & 4.48 & 0.63 \\
\hline Most of my friends are from the same COO. & 5.03 & 0.80 \\
\hline
\end{tabular}


Table 1: Constructs' information - continued

\begin{tabular}{|c|c|c|}
\hline & $\begin{array}{r}\text { Mean } \\
\text { values }\end{array}$ & $\begin{array}{c}\text { Alpha, CR, Ave \& } \\
\text { Factor loadings }\end{array}$ \\
\hline Entrepreneurial orientation (EO) (Covin \& Slevin, 1989) & & $\begin{array}{c}\alpha=0.91 \\
\mathrm{CR}=0.93\end{array}$ \\
\hline $\begin{array}{l}\text { In general, when operating in the host market, the top managers } \\
\text { of our firm favor } \\
\text { (1= strong emphasis on the marketing of tried and true } \\
\text { products/services; } 7=\text { strong emphasis on } R \& D \text {, technological } \\
\text { leadership, and innovations) }\end{array}$ & 4.48 & 0.57 \\
\hline $\begin{array}{l}\text { In dealing with its competitors in the host market, our firm: } \\
\text { (1= Typically responds to actions which competitors initiate, } \\
7=\text { Typically initiates actions which competitors then respond to) } \\
\text { (1=Is very seldom the first business to introduce new } \\
\text { products/services, administrative techniques, operating } \\
\text { technologies, etc., } 7=\text { Is very often the first business to introduce } \\
\text { new product/services, administrative techniques, operating } \\
\text { technologies, etc.) } \\
\text { (1=Typically seeks to avoid competitive clashes, preferring a } \\
\text { "live-and-let-live" posture, } 7=\text { Typically adopts a very } \\
\text { competitive, "undo-the-competitors" posture) }\end{array}$ & $\begin{array}{l}4.31 \\
4.21\end{array}$ & $\begin{array}{l}0.80 \\
0.83\end{array}$ \\
\hline $\begin{array}{l}\text { In general, when operating in the host market, the top managers } \\
\text { of our firm have: } \\
\text { ( } 1=A \text { strong proclivity for low-risk projects (with normal \& } \\
\text { certain rates of return, } 7=A \text { strong proclivity for high-risk } \\
\text { projects (with chances of very high returns)) }\end{array}$ & 4.02 & 0.83 \\
\hline $\begin{array}{l}\text { In general, the top managers of our firm believe that: } \\
\text { ( } 1=\text { Owing to the nature of the environment, it is best to explore } \\
\text { it gradually via timid, incremental behavior; } 7=\text { Owing to the } \\
\text { nature of the environment, bold, wide-ranging acts are } \\
\text { necessary to achieve the firm's objectives) }\end{array}$ & 4.01 & 0.86 \\
\hline $\begin{array}{l}\text { When confronted with decision-making situations involving } \\
\text { uncertainty in the host market, our firm: } \\
\text { ( } 1=\text { Typically adopts a cautious, "wait-and-see" posture in } \\
\text { order to minimize the probability of making costly decisions; } 7= \\
\text { Typically adopts a bold, aggressive posture in order to maximize } \\
\text { the probability of exploiting potential opportunities) }\end{array}$ & 4.20 & 0.77 \\
\hline
\end{tabular}


Table 2: Correlation coefficients of the key variables $(\mathrm{N}=167)$

\begin{tabular}{|c|c|c|c|c|c|c|c|c|c|c|c|c|}
\hline & Mean & 1 & 2 & 3 & 4 & 5 & 6 & 7 & 8 & 9 & 10 & 11 \\
\hline 1. Innovation & 4.30 & 1 & $0.310^{* *}$ & $0.111^{*}$ & 0.056 & $-0.124^{*}$ & -0.088 & $0.131^{*}$ & 0.042 & $0.157^{* *}$ & $0.292^{* *}$ & $0.180^{* *}$ \\
\hline $\begin{array}{l}\text { 2. Entrepreneurial } \\
\text { orientation }\end{array}$ & 4.24 & $0.311^{* *}$ & 1 & -0.024 & 0.040 & -0.084 & -0.081 & -0.043 & $0.145^{*}$ & $0.124^{*}$ & $0.121^{*}$ & 0.107 \\
\hline 3. Business ties & 4.52 & $0.112^{*}$ & -0.023 & 1 & $0.252^{* *}$ & $-0.178^{* *}$ & -0.027 & $0.178^{*}$ & -0.111 & -0.110 & 0.097 & -0.018 \\
\hline 4. Political ties & 4.02 & 0.057 & 0.041 & $0.253^{* *}$ & & -0.063 & 0.093 & $0.130^{*}$ & -0.081 & -0.004 & 0.054 & 0.035 \\
\hline $\begin{array}{l}\text { 5. Immigrant } \\
\text { owner ethnic } \\
\text { immigrant ties }\end{array}$ & 4.89 & $-0.123^{*}$ & -0.083 & $-0.177^{* *}$ & -0.062 & 1 & -0.045 & $-0.143^{*}$ & 0.115 & $-0.141^{*}$ & -0.060 & 0.087 \\
\hline 6. Industry sector & NA & -0.087 & -0.080 & -0.026 & 0.094 & -0.044 & 1 & 0.106 & $-0.214^{*}$ & -0.081 & 0.131 & 0.000 \\
\hline $\begin{array}{l}\text { 7. Immigrant } \\
\text { owner experience }\end{array}$ & 14.00 & $0.132^{*}$ & -0.042 & $0.179^{* *}$ & $0.131^{*}$ & $-0.142^{*}$ & 0.107 & 1 & $-0.258^{* *}$ & 0.075 & $0.138^{*}$ & 0.006 \\
\hline $\begin{array}{l}\text { 8. Whether } \\
\text { exporting }\end{array}$ & NA & 0.043 & $0.146^{*}$ & -0.110 & -0.080 & 0.116 & $-0.213^{*}$ & $-0.257^{* *}$ & 1 & 0.016 & -0.125 & 0.078 \\
\hline $\begin{array}{l}\text { 9. Competitive } \\
\text { rivalry }\end{array}$ & 4.40 & $0.158^{* *}$ & $0.125^{*}$ & -0.109 & -0.003 & $-0.140^{*}$ & -0.080 & 0.076 & 0.017 & 1 & 0.080 & 0.004 \\
\hline $\begin{array}{l}\text { 10. Technological } \\
\text { turbulence }\end{array}$ & 3.91 & $0.293^{* *}$ & $0.122^{*}$ & 0.098 & 0.055 & -0.059 & 0.132 & $0.139^{*}$ & -0.124 & 0.081 & 1 & 0.060 \\
\hline $\begin{array}{l}\text { 11. Conflicts } \\
\text { (Marker variable) }\end{array}$ & 4.23 & $0.181^{* *}$ & 0.108 & -0.017 & 0.036 & 0.088 & 0.001 & 0.007 & 0.079 & 0.005 & 0.061 & 1 \\
\hline
\end{tabular}

*: $\mathrm{p}<0.05 ;{ }^{* *}: \mathrm{p}<0.01$. The adjusted correlations for potential common method variance are listed above the diagonal (Lindell \&Whitney, 2001). 
Table 3. Regression results ${ }^{\mathrm{a}}$

\begin{tabular}{|c|c|c|c|c|c|c|}
\hline & \multicolumn{6}{|c|}{ Innovation } \\
\hline & M1 & VIF & M2 & VIF & M3 & VIF \\
\hline \multicolumn{7}{|l|}{ Control variables } \\
\hline Industry sector & $-.161+$ & 1.143 & -.123 & 1.165 & -.068 & 1.211 \\
\hline Immigrant owner experience & $.264 * *$ & 1.156 & $.256^{* *}$ & 1.365 & $.188 *$ & 1.547 \\
\hline Whether exporting & .103 & 1.158 & .066 & 1.187 & .039 & 1.200 \\
\hline Competitive rivalry & .109 & 1.062 & .039 & 1.280 & -.027 & 1.350 \\
\hline Technological turbulence & $.350 * *$ & 1.130 & $.310 * *$ & 1.212 & $.283 * *$ & 1.260 \\
\hline \multicolumn{7}{|l|}{ Direct effect variables } \\
\hline Entrepreneurial orientation & & & $.357 * *$ & 1.235 & .146 & 3.421 \\
\hline Business ties & & & .126 & 1.555 & $.201 *$ & 1.709 \\
\hline Political ties & & & -.064 & 1.584 & -.106 & 1.678 \\
\hline $\begin{array}{l}\text { Immigrant owner immigrant } \\
\text { ties }\end{array}$ & & & -.032 & 1.312 & -.039 & 1.428 \\
\hline \multicolumn{7}{|l|}{ Interactions } \\
\hline $\begin{array}{l}\text { Entrepreneurial orientation } \mathrm{x} \\
\text { Business ties }\end{array}$ & & & & & $.490 * *$ & 4.335 \\
\hline $\begin{array}{l}\text { Entrepreneurial orientation } \mathrm{x} \\
\text { Political ties }\end{array}$ & & & & & -.214 & 3.874 \\
\hline $\begin{array}{l}\text { Entrepreneurial orientation } \mathrm{x} \\
\text { Immigrant owner immigrant } \\
\text { ties }\end{array}$ & & & & & $.185^{*}$ & 1.400 \\
\hline $\mathrm{R}^{2}$ value & \multicolumn{2}{|c|}{$.237 * *$} & \multicolumn{2}{|c|}{$.367 * *$} & \multicolumn{2}{|c|}{$.432 * *$} \\
\hline Adjusted $\mathrm{R}^{2}$ value & \multicolumn{2}{|c|}{$.204^{* *}$} & \multicolumn{2}{|c|}{$.317 * *$} & \multicolumn{2}{|c|}{$.370 * *$} \\
\hline $\mathrm{R}^{2}$ value change & \multicolumn{2}{|c|}{$.237 * *$} & & \multicolumn{2}{|c|}{$.065 * *$} \\
\hline F value & \multicolumn{2}{|c|}{$7.319 * *$} & & $7.342 * *$ & \multicolumn{2}{|c|}{$7.033 * *$} \\
\hline
\end{tabular}

${ }^{a}$ All beta values are standardized. +: $\mathrm{p}<0.1 ;{ }^{*}: \mathrm{p}<0.05 ;{ }^{*}$ : $\mathrm{p}<0.01$. 
Appendix

Table Appendix 1. Regression results ${ }^{\mathrm{a}}$

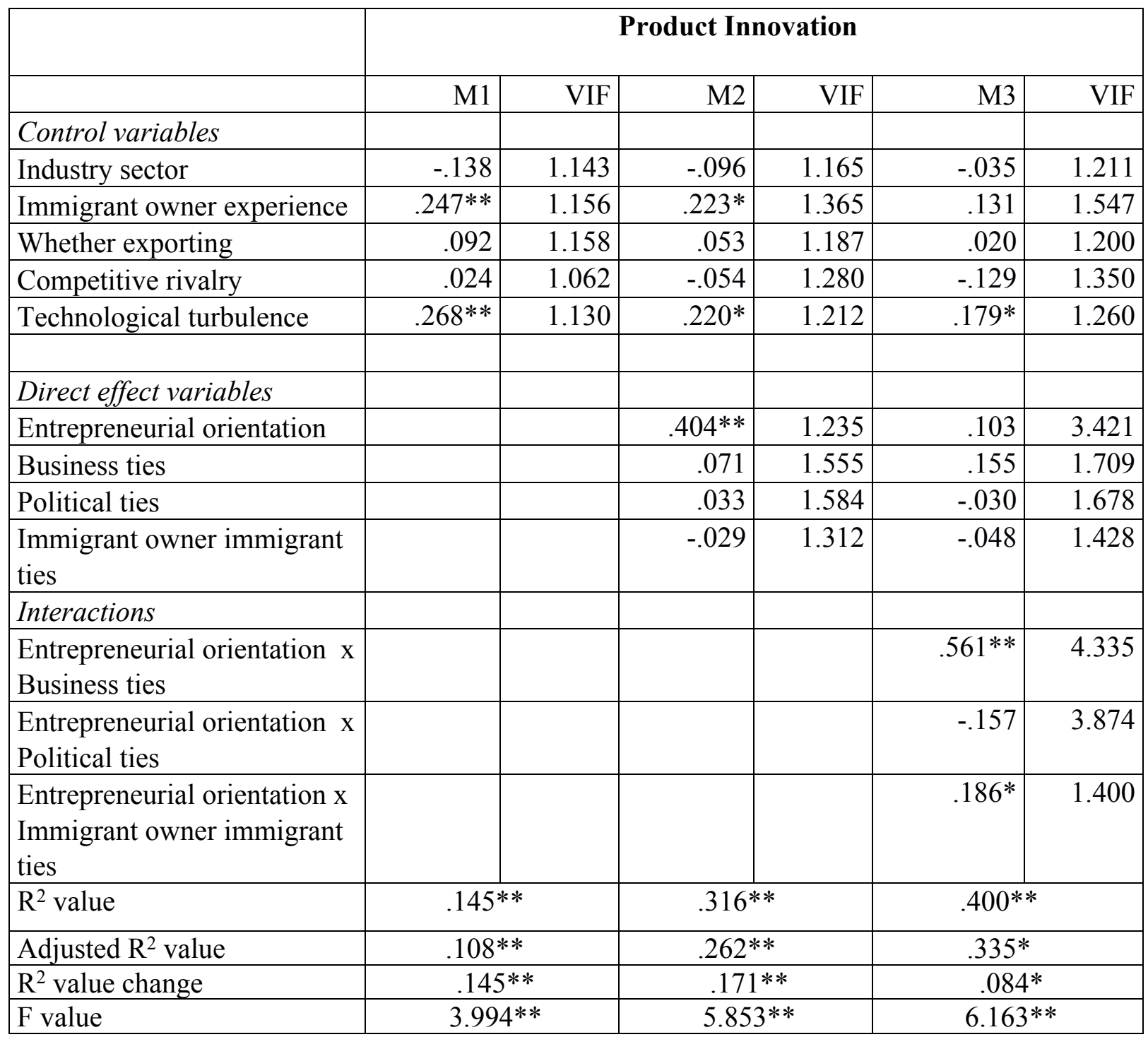

${ }^{a}$ All beta values are standardized. $+: \mathrm{p}<0.1 ; *: \mathrm{p}<0.05 ;{ }^{* *}: \mathrm{p}<0.01$. 
Table Appendix 2. Regression results ${ }^{\mathrm{a}}$

\begin{tabular}{|c|c|c|c|c|c|c|}
\hline & \multicolumn{6}{|c|}{ Process Innovation } \\
\hline & M1 & VIF & M2 & VIF & M3 & VIF \\
\hline \multicolumn{7}{|l|}{ Control variables } \\
\hline Industry sector & $-.154+$ & 1.143 & -.114 & 1.165 & -.068 & 1.211 \\
\hline Immigrant owner experience & $.209 *$ & 1.156 & $.192 *$ & 1.365 & $.149+$ & 1.547 \\
\hline Whether exporting & .079 & 1.158 & .042 & 1.187 & .023 & 1.200 \\
\hline Competitive rivalry & .131 & 1.062 & .066 & 1.280 & .009 & 1.350 \\
\hline Technological turbulence & $.376^{* *}$ & 1.130 & $.329 * *$ & 1.212 & $.315 * *$ & 1.260 \\
\hline \multicolumn{7}{|l|}{ Direct effect variables } \\
\hline Entrepreneurial orientation & & & $.362 * *$ & 1.235 & .266 & 3.421 \\
\hline Business ties & & & .155 & 1.555 & $.222 *$ & 1.709 \\
\hline Political ties & & & -.063 & 1.584 & -.082 & 1.678 \\
\hline $\begin{array}{l}\text { Immigrant owner immigrant } \\
\text { ties }\end{array}$ & & & -.036 & 1.312 & -.033 & 1.428 \\
\hline \multicolumn{7}{|l|}{ Interactions } \\
\hline $\begin{array}{l}\text { Entrepreneurial orientation } \mathrm{x} \\
\text { Business ties }\end{array}$ & & & & & $.411 * *$ & 4.335 \\
\hline $\begin{array}{l}\text { Entrepreneurial orientation } \mathrm{x} \\
\text { Political ties }\end{array}$ & & & & & $-.294 *$ & 3.874 \\
\hline $\begin{array}{l}\text { Entrepreneurial orientation } \mathrm{x} \\
\text { Immigrant owner immigrant } \\
\text { ties }\end{array}$ & & & & & $.169 *$ & 1.400 \\
\hline $\mathrm{R}^{2}$ value & \multicolumn{2}{|c|}{$.237 * *$} & \multicolumn{2}{|c|}{$.378 * *$} & \multicolumn{2}{|c|}{$.431 * *$} \\
\hline Adjusted $\mathrm{R}^{2}$ value & \multicolumn{2}{|c|}{$.204 * *$} & \multicolumn{2}{|c|}{$.329 * *$} & \multicolumn{2}{|c|}{$.369^{*}$} \\
\hline $\mathrm{R}^{2}$ value change & \multicolumn{2}{|c|}{$.237 * *$} & \multicolumn{2}{|c|}{$.141 * *$} & \multicolumn{2}{|c|}{$.053^{*}$} \\
\hline F value & \multicolumn{2}{|c|}{$7.315 * *$} & \multicolumn{2}{|c|}{$7.695 * *$} & \\
\hline
\end{tabular}

${ }^{a}$ All beta values are standardized. $+: \mathrm{p}<0.1 ; *: \mathrm{p}<0.05 ; * *: \mathrm{p}<0.01$. 
Table Appendix 3. Regression results ${ }^{\mathrm{a}}$

\begin{tabular}{|c|c|c|c|c|c|c|}
\hline & \multicolumn{6}{|c|}{ Administrative Innovation } \\
\hline & M1 & VIF & M2 & VIF & M3 & VIF \\
\hline \multicolumn{7}{|l|}{ Control variables } \\
\hline Industry sector & $-.152+$ & 1.143 & -.128 & 1.165 & -.084 & 1.211 \\
\hline Immigrant owner experience & $.276^{* *}$ & 1.156 & $.293 * *$ & 1.365 & $.236^{*}$ & 1.547 \\
\hline Whether exporting & .114 & 1.158 & .087 & 1.187 & .064 & 1.200 \\
\hline Competitive rivalry & $.143+$ & 1.062 & .090 & 1.280 & .036 & 1.350 \\
\hline Technological turbulence & $.320 * *$ & 1.130 & $.305^{* *}$ & 1.212 & $.282 * *$ & 1.260 \\
\hline \multicolumn{7}{|l|}{ Direct effect variables } \\
\hline Entrepreneurial orientation & & & $.229 *$ & 1.235 & .033 & 3.421 \\
\hline Business ties & & & .120 & 1.555 & $.178+$ & 1.709 \\
\hline Political ties & & & -.140 & 1.584 & $-.178+$ & 1.678 \\
\hline $\begin{array}{l}\text { Immigrant owner immigrant } \\
\text { ties }\end{array}$ & & & -.023 & 1.312 & -.027 & 1.428 \\
\hline \multicolumn{7}{|l|}{ Interactions } \\
\hline $\begin{array}{l}\text { Entrepreneurial orientation } \mathrm{x} \\
\text { Business ties }\end{array}$ & & & & & $.392 *$ & 4.335 \\
\hline $\begin{array}{l}\text { Entrepreneurial orientation } \mathrm{x} \\
\text { Political ties }\end{array}$ & & & & & -.138 & 3.874 \\
\hline $\begin{array}{l}\text { Entrepreneurial orientation } \mathrm{x} \\
\text { Immigrant owner immigrant } \\
\text { ties }\end{array}$ & & & & & $.160+$ & 1.400 \\
\hline $\mathrm{R}^{2}$ value & \multicolumn{2}{|c|}{$.237 * *$} & \multicolumn{2}{|c|}{.294+ } & \multicolumn{2}{|c|}{$.338+$} \\
\hline Adjusted $\mathrm{R}^{2}$ value & \multicolumn{2}{|c|}{$.205^{* *}$} & \multicolumn{2}{|c|}{$.239+$} & \multicolumn{2}{|c|}{$.267+$} \\
\hline $\mathrm{R}^{2}$ value change & \multicolumn{2}{|c|}{$.237 * *$} & \multicolumn{2}{|c|}{$.057+$} & \multicolumn{2}{|c|}{$.044+$} \\
\hline F value & \multicolumn{2}{|c|}{$7.333 * *$} & \multicolumn{2}{|c|}{$5.287 * *$} & \multicolumn{2}{|c|}{$4.726 * *$} \\
\hline
\end{tabular}

${ }^{a}$ All beta values are standardized. $+: \mathrm{p}<0.1 ; *: \mathrm{p}<0.05 ;{ }^{* *}: \mathrm{p}<0.01$. 